\title{
Prevalence of serum antibodies against Saprolegnia parasitica in wild and farmed brown trout Salmo trutta
}

\author{
J. M. Fregeneda-Grandes, M. T. Carbajal-González, J. M. Aller-Gancedo* \\ Departamento de Sanidad Animal, Facultad de Veterinaria, Universidad de León, 24071 León, Spain
}

\begin{abstract}
The prevalence of serum antibodies against Saprolegnia parasitica in wild and farmed brown trout Salmo trutta from the province of León (NW Spain) was studied by enzyme-linked immunosorbent assay (ELISA). Blood samples from healthy and Saprolegnia-infected brown trout were collected over 2 yr with a seasonal periodicity (January, April, July and October) from a hatchery and river with frequent presence of saprolegniosis (River Porma) and from a river in which the disease was rarely observed (River Omaña). The individual prevalence was $30.1 \%$, but statistically significant differences were observed between the prevalence in trout from the hatchery $(43.0 \%)$, from River Porma (31.8\%) and from River Omaña (6.4\%) and also between the prevalence observed in October $(42.9 \%)$ and the values obtained in January $(24.8 \%)$, April $(22.7 \%)$ and July $(27.5 \%)$. There was no difference between the seroprevalence in females $(34.8 \%)$ and males $(38.2 \%)$, but a positive correlation between raised serum antibody levels and larger (older) fish was found. The low prevalence of antibodies observed in Saprolegnia-infected trout (18.0\%) suggests possible immune suppression and the lack of an effective specific immune response in fish with saprolegniosis.
\end{abstract}

KEY WORDS: Saprolegnia parasitica $\cdot$ Brown trout $\cdot$ Serum antibodies $\cdot$ Prevalence $\cdot$ ELISA

\section{INTRODUCTION}

Saprolegniosis, caused by Saprolegnia spp., is an important freshwater fish disease, which often affects wild and farmed salmonids. In salmonid fish farms saprolegniosis affects mainly broodfish and incubating eggs, causing major financial losses (Pickering \& Willoughby 1982, Noga 1993, Bruno \& Wood 1999). In rivers and lakes saprolegniosis can reduce the natural salmonid populations, as has occurred amongst wild brown trout Salmo trutta in several rivers in the province of León in Spain (Aller-Gancedo \& Fernández-Díez 1986).

It has been suggested that the mucus layer, the integrity of the epidermis and a cellular response based on non-specific phagocytic activity of inflammatory cells play an important role in the defence mechanisms of fish against saprolegniosis, whereas the par- ticipation of a specific immune response is uncertain (Hodkinson \& Hunter 1970, Sohnle \& Chusid 1983, Wood et al. 1986, Pickering 1994). Results from studies on the production of antibodies against Saprolegnia infection in fish are contradictory, depending on the species studied, the water temperature, and the antigens and serological techniques used (Hodkinson \& Hunter 1970, El-Feki 1987, Sohnle \& Chusid 1983, Bly et al. 1994). For example, El-Feki (1987) did not find any serological response in carp intraperitoneally injected with soluble or hyphal extracts of $S$. diclina or in carp experimentally infected with $S$. diclina, but he did detect antibodies in rainbow trout with saprolegniosis from a fish farm. Moreover, Sohnle \& Chusid (1983) and Bly et al. (1994) did not find precipitating antibodies in rainbow trout or channel catfish, respectively, following experimental inoculation with Saprolegnia sp. isolates. In contrast, Hodkinson \& Hunter 
(1970) found them in $93 \%$ of the wild salmon studied but only $66 \%$ of these were colonized by Saprolegnia spp. Fregeneda-Grandes et al. (2007) demonstrated that brown trout injected with antigenic extracts from a pathogenic isolate of Saprolegnia parasitica are able to develop specific antibodies against them that can be detected by standard immunological techniques such as enzyme-linked immunosorbent assay (ELISA), immunofluorescence (IF) and western blotting (WB). The results obtained by using these various techniques were similar, showing there is cross-reaction between the antigenic extracts used, but ELISA detected the greatest number of positive samples. The aim of the present study was to research the prevalence of serum antibodies against $S$. parasitica in wild and farmed brown trout from both healthy and naturally Saprolegnia-infected fish to gain a better understanding of the specific immune response against Saprolegnia infections.

\section{MATERIALS AND METHODS}

Fish and samples. The study was conducted in the province of León in northwest Spain. Healthy and Saprolegnia-infected brown trout Salmo trutta were collected over a period of $2 \mathrm{yr}$ (October 2002 to July 2004) with a seasonal periodicity (January, April, July and October). Samples were collected from 3 locations: 2 with frequent presence of saprolegniosis during the spawning season in recent years, a hatchery situated on the River Porma and owned by the Castile and Leon Regional Government (Junta de Castilla y León) and the River Porma itself; and the third a river in which the disease has never or rarely been observed, the River Omaña. At the River Omaña, samples were taken 5 times between October 2002 and October 2003. As saprolegniosis affects mainly sexually mature fish, blood samples were taken from broodfish at the hatchery and from wild brown trout $>17 \mathrm{~cm}$ in length. At the hatchery, broodfish were maintained in raceways (one for females and another for males) situated in the open with a continuous supply of well water. They were sampled when $3 \mathrm{yr}$ old (in the first year of the study) and $4 \mathrm{yr}$ old (in the second year). Wild brown trout were captured by electrofishing at different sampling points between Candanedo de Boñar and Santibañez del Porma on the River Porma, and between Villanueva de Omaña and Guisatecha on the River Omaña. The water temperature at the sampling points varied between seasons from 7 to $13^{\circ} \mathrm{C}$ at the hatchery, from 6 to $14^{\circ} \mathrm{C}$ in the River Porma and from 4 to $14^{\circ} \mathrm{C}$ in the River Omaña. Required sample sizes were calculated using Win Episcope 2.0 (CLIVE), based on the population data for broodfish at the hatchery $(\mathrm{n}=$
1600), an expected prevalence of $50 \%$, an accepted error of $10 \%$ and a $95 \%$ confidence level. The sample size calculated was 91, but to avoid loss of information in the analyses, the sample was increased by $5 \%$. In the end, 96 samples were randomly selected in each season and taken from the 3 populations studied, except the River Omaña, where it was only possible to take 84 samples in January 2003. At the hatchery, half of the samples were taken from females and half from males, except at the first sampling (October 2002, all broodfish kept together until first spawning). In total, 2004 blood samples were investigated (1236 from wild brown trout and 768 from broodfish), of which only $23(1.1 \%)$ were from Saprolegnia-infected fish (see Table 1).

In view of the small number of samples from fish with saprolegniosis, a further 2 specific groups of Saprolegnia-infected male broodfish from the hatchery were sampled over 6 to $12 \mathrm{wk}$ in order to study the presence of serum antibodies related to the disease. The first group (Group 1) was made up of 57 males with saprolegniosis, which were kept separate in a raceway and did not receive any treatment. Group 1 had $100 \%$ mortality within a period of $51 \mathrm{~d}$ (January to March 2003). These fish were sampled on the first day, and then samples were taken from fish alive at 7,14 , 21,35 and $43 \mathrm{~d}$ to obtain a total of 148 blood samples $(57,43,24,16,5$ and 3 samples, respectively). The second group (Group 2) were trout from a raceway that contained 253 males kept under normal hatchery conditions; they received preventive treatments against saprolegniosis (Proxitane 0510, Solvay Interox). Fish with saprolegniosis were observed very frequently in this raceway and they presented a cumulative mortality of $36.8 \%$ during the study (January to April 2004). Blood samples were taken from 48 trout from Group 2 every 4 wk (Days 0, 28, 55 and 83) with a total of 192 samples, 68 from Saprolegnia-infected fish (48 in January, 17 in February and 3 in March) and 124 from trout without saprolegniosis (31 in February, 45 in March and 48 in April). All the trout were anaesthetized with $50 \mathrm{mg} \mathrm{l}^{-1}$ of MS 222 (tricaine methane sulphonate), weighed and measured, then individual blood samples were obtained by puncturing the caudal vein. All the trout were returned alive to the water with the exception of trout with saprolegniosis from the rivers. After clotting overnight at $4{ }^{\circ} \mathrm{C}$, the blood samples were centrifuged at $1000 \times g$ for $45 \mathrm{~min}$ to obtain the serum. Sera were stored at $-20^{\circ} \mathrm{C}$ until they were used.

Antibody detection. The presence of antibodies in the serum was analyzed by ELISA using a soluble antigenic extract from sonicated formalinized mycelia of a pathogenic isolate of Saprolegnia parasitica, as described in Fregeneda-Grandes et al. (2007). Serial 2-fold dilutions 
(1:20 to $1: 10240)$ of trout serum were used and the ELISA titre was defined as a reciprocal value of the highest serum dilution giving an optical density (OD) value >0.5 (mean OD values for the negative control sera plus 3 SD). Only titres of 40 or higher were considered positive.

In addition, 271 representative trout sera from the various fish samples, including some from the 2 groups of males with saprolegniosis (218 from trout without saprolegniosis and 53 from trout with saprolegniosis), were selected to perform a WB analysis, in order to identify individual proteins in the soluble antigenic extract recognized by the trout sera. WB was performed as described in FregenedaGrandes et al. (2007).

Statistics. Chi-squared tests were used to compare seroprevalence rates with relation to origin, season, sex, length-group and the presence of saprolegniosis. Confidence limits for the proportions were established by an exact binomial test with a $95 \%$ CI. For statistical purposes the titres were transformed to a logarithmic scale and differences in the mean $\log _{10}$ titres for positive fish were analysed statistically by means of the parametric ANOVA or the non-parametric Kruskall-Wallis test, depending on whether the conditions for a classical ANOVA were fulfilled or not. All statistical tests were done with Epi Info software for Windows, Version 3.3 (Centers for Disease Control); $\mathrm{p}<0.05$ was taken as statistically significant.

\section{RESULTS}

Antibodies were found in 30.1\% (95\% CI: 28.1-32.2) of the serum samples analyzed (604 of 2004) in the seasonal study. However, statistically significant differences $(p<0.001)$ were observed between the prevalence in the trout from the hatchery $(43.0 \%$, 39.4-46.6), the River Porma (31.8\%, 28.5-35.2) and the River Omaña $(6.4 \%, 4.4-9.1)$ (Table 1). With regard to the season, the prevalence observed in October $(42.9 \%)$ was significantly different $(\mathrm{p}<0.001)$ from that obtained in January $(24.8 \%)$, April $(22.7 \%)$ and July (27.5\%). The seroprevalences among males $(38.2 \%, 33.4-43.1)$ and females $(34.8 \%, 30.0-39.9)$ were not significantly different $(\mathrm{p}=0.37)$ but a positive relation was found between size (length-group) and seroprevalence $(p<0.001)$ : prevalence tended to increase with the length of the trout. The lowest seroprevalence values were found in trout less than $26 \mathrm{~cm}$

Table 2. Distribution of serum ELISA titres of antibodies against Saprolegnia parasitica in wild and farmed brown trout Salmo trutta (includes fish from the seasonal study and Groups 1 and 2)

\begin{tabular}{|lcc|}
\hline Titre & $\begin{array}{c}\text { Without saprolegniosis } \\
\text { no. sera (\% total) }\end{array}$ & $\begin{array}{c}\text { With saprolegniosis } \\
\text { no. sera (\% total) }\end{array}$ \\
\hline 40 & $207(33.3)$ & $13(30.2)$ \\
80 & $189(30.5)$ & $15(34.9)$ \\
160 & $113(18.2)$ & $9(20.9)$ \\
320 & $71(11.4)$ & $3(7.0)$ \\
640 & $25(4.1)$ & $0(0)$ \\
1280 & $12(1.9)$ & $2(4.7)$ \\
2560 & $4(0.6)$ & $0(0)$ \\
5120 & $0(0)$ & $0(0)$ \\
10240 & $0(0)$ & $1(2.3)$ \\
Total & $621(100)$ & $43(100)$ \\
\hline
\end{tabular}


ence or absence of the disease, the season and the size of the fish, which is directly related to their age. It is well known that temperature, photoperiod and other environmental conditions, which vary seasonally, may have an impact on the immune system of fish (Bowden et al. 2007). Generally, higher temperatures (in the physiologically normal range) have been reported to enhance immune responses in fish, whereas lower temperatures adversely affect immune function (Bly \& Clem 1992). However, in the present study, the prevalence of anti-Saprolegnia antibodies observed in the samples taken in January (with a water temperature between 4 and $7^{\circ} \mathrm{C}$ ) was no different from that observed in April $\left(7\right.$ to $\left.11^{\circ} \mathrm{C}\right)$ or July $\left(10\right.$ to $\left.14^{\circ} \mathrm{C}\right)$. The differences in seasonal prevalence observed might be related to the seasonal periodicity of Saprolegniaceae in northwestern Spain (Fregeneda-Grandes 1998); higher concentrations of spores were found to be present in water at the end of the summer (August to September) and early autumn (October). This might explain the fact that the highest prevalence of antibodies was found in October (Table 1). In the present study, the difference between the prevalence in males and in females was not significant, despite the fact that Wilson (1976) noted a reduced immune response capacity against Saprolegnia antigens in mature males.

Surprisingly, the prevalence of serum antibodies in brown trout with saprolegniosis was lower than in clinically healthy fish and, curiously, in those trout that showed the most severe lesions. These results are in agreement with Hodkinson \& Hunter (1970), who used double gel diffusion to test sera from wild salmon Salmo salar L. affected by saprolegniosis and observed less reactivity in sera from more heavily colonized fish, because they showed a smaller average number of precipitation lines than salmon not affected or having only slight lesions. This phenomenon could be related to the haemodilution observed in Saprolegnia-infected fish (Pickering \& Willoughby 1982), more severe in the present study because some trout from the 2 specific groups studied at the hatchery were bled several times in a short period. It is also possible that during the acute phase of the disease, serum antibodies were removed from the blood by adsorption with the antigens and could not be detected by standard serological techniques (Hodkinson \& Hunter 1970, Wilson 1976). However, the same distribution and mean log titres were observed in positive samples from fish with or without saprolegniosis. Other authors have tried to characterize the immune response, both cellular and humoral, against Saprolegnia infection and have shown evidence of a lack of an effective response, which might favour the course of the disease (Sohnle \& Chusid 1983, El-Feki 1987, Álvarez et al. 1988, 1995, Bly et al. 1994). Results from the present study are along the same lines. It is not clear whether fish with saprolegniosis are immunocompromised prior to infection (as a consequence of low water temperature or high circulating corticosteroids), or whether Saprolegnia can produce cytotoxic or other virulence factors to evade or suppress the immune system. Host defence suppression by Saprolegnia remains poorly understood, but recently Kales et al. (2007) have suggested that inhibition of phagocytosis due to the large spore size and the reduction of macrophage gene expression of the class II major histocompatibility (MH II) receptor and associated molecules, which play a crucial role in the recognition of exogenous antigens, may suppress the host immune response. Moreover, Torto-Alalibo et al. (2005) generated a large number of expressed sequence tags from a mycelial cDNA library of Saprolegnia parasitica and discovered several proteins that may be implicated in protein translocation process into host cells; Van West (2006) speculated that some of these proteins might be responsible for suppressing the immune response in the host.

In the present study, a smaller number of positive samples were found by WB than by ELISA; similar results were obtained previously by using various techniques to detect serum antibodies in brown trout intraperitoneally injected with antigenic extracts from a pathogenic isolate of Saprolegnia parasitica (Fregeneda-Grandes et al. 2007). Nevertheless, a greater number of positive samples was detected by ELISA, followed by immunofluorescence and finally by WB. Moreover, trout experimentally injected with $S$. parasitica antigens recognized a larger number of bands ( 1 to 8$)$ than trout in the present study (1 to 2 bands), which may reflect differences in the immune response against Saprolegnia antigens when fish are naturally exposed. Lorenzen \& LaPatra (1999) noted the poor reactivity of rainbow trout sera to viral antigens in WB. They found that sera from trout that survived natural infection with viral haemorrhagic septicaemia virus did not react in $\mathrm{WB}_{\text {; }}$ these fish showed a detectable antibody response only to certain viral proteins and only after immunization with whole virus particles. The 2 bands most frequently recognized in brown trout naturally and experimentally exposed to Saprolegnia antigens were 2 proteins of 25 and $29 \mathrm{kDa}$ (FregenedaGrandes et al. 2007, present study). This suggests that these 2 proteins may be the most immunogenic and studies to characterize them are in progress.

In conclusion, the present study contributes to a better understanding of the specific immune response against Saprolegnia infections. Further studies will focus on the factors that might influence the humoral immune response and the possible role of the antibodies in protection against saprolegniosis. 
Acknowledgements. This study was supported by the research project AGL2002-00505 financed by the Spanish Ministry of Science and Technology (Ministerio de Ciencia y Tecnología) and the European Regional Development Fund. M.T.C.G. was a fellowship holder from the Regional Government of Castile and León (Junta de Castilla y León). We are likewise grateful to the Junta de Castilla y León, especially to J. Sancho, M. de Celis and A. Sánchez of the León District Environmental Service (Servicio Territorial de Medio Ambiente de León) for providing the fish and hatchery facilities, and to the EU Reference Laboratory for Fish Diseases (Aarhus, Denmark) for supplying anti-rainbow trout IgM monoclonal antibody.

\section{LITERATURE CITED}

Aller-Gancedo JM, Fernández-Díez M (1986) Saprolegnia infection in wild brown trout (Salmo trutta) in the rivers of León (Spain). Z Bakteriol Hygiene 262:17-18

Álvarez F, Razquin B, Villena A, López-Fierro P, Zapata A (1988) Alterations in the peripheral lymphoid organs and differential leukocyte counts in Saprolegnia-infected brown trout, Salmo trutta fario. Vet Immunol Immunopathol 18:181-193

Álvarez F, Villena A, Zapata A, Razquin B (1995) Histopathology of the thymus in Saprolegnia-infected wild brown trout, Salmo trutta L. Vet Immunol Immunopathol 47:163-172

Bly JE, Clem LW (1992) Temperature and teleost immune functions. Fish Shellfish Immunol 2:159-171

Bly JE, Lawson LA, Abdel-Aziz ES, Clem LW (1994) Channel catfish, Ictalurus punctatus, immunity to Saprolegnia sp. J Appl Aquacult 3:35-50

Bowden TJ, Thompson KD, Morgan AL, Gratacap RML, Nikoskelainen S (2007) Seasonal variation and the immune response: a fish prespective. Fish Shellfish Immunol 22:695-706

Bruno DW, Wood BP (1999) Saprolegnia and other Oomycetes. In: Woo PTK, Bruno DW (eds) Fish diseases and disorders, Vol 3: viral, bacterial and fungal infections. CABI Publishing, CAB International, Wallingford, p 599-659

El-Feki MA (1987) Studies on the host-parasite interaction between carp and Saprolegnia. PhD thesis, University of Aston, Birmingham

Fregeneda-Grandes JM (1998) Presencia de Saprolegnia en

Editorial responsibility: David Bruno,

Aberdeen, UK agua del río Luna (León). Características ultraestructurales y patogenicidad experimental para la trucha arco iris (Oncorhynchus mykiss) de las cepas potencialmente patógenas. PhD thesis, University of León, Spain

> Fregeneda-Grandes JM, Rodríguez-Cadenas F, CarbajalGonzález MT, Aller-Gancedo JM (2007) Antibody response of brown trout Salmo trutta injected with pathogenic Saprolegnia parasitica antigenic extracts. Dis Aquat Org 74:107-111

Hodkinson M, Hunter A (1970) Immune response of U.D.N.infected salmon to Saprolegnia. J Fish Biol 2:305-311

Kales SC, DeWitte-Orr SJ, Bols NC, Dixon B (2007) Response of the rainbow trout monocyte/macrophage cell line, RTS11 to the water molds Achlya and Saprolegnia. Mol Immunol 44:2303-2314

> Lorenzen N, LaPatra SE (1999) Immunity to rhabdoviruses in rainbow trout: the antibody response. Fish Shellfish Immunol 9:345-360

Noga EJ (1993) Water mold infections of freshwater fish: recent advances. Annu Rev Fish Dis 3:291-304

Pickering AD (1994) Factors influencing the susceptibility of salmonid fish to saprolegniasis. In: Mueller GJ (ed) Salmon saprolegniosis. US Department of Energy, Bonneville Power Administration, Portland, OR, p 67-86

Pickering AD, Willoughby LG (1982) Saprolegnia infections of salmonid fish. In: Roberts RJ (ed) Microbial diseases of fish. Academic Press, London, p 271-297

Sohnle PG, Chusid MJ (1983) Defence against infection with filamentous fungi in rainbow trout. Comp Biochem Physiol A 74:71-76

Torto-Alalibo $\mathrm{T}$, Tian M, Gajendran K, Waugh ME, van West P, Kamoun S (2005) Expressed sequence tags from the oomycete fish pathogen Saprolegnia parasitica reveal putative virulence factors. BMC Microbiol 5:46, doi: 10.1186/1471-2180-5-46

> Van West P (2006) Saprolegnia parasitica, an oomycete pathogen with a fishy appetite: new challenges for an old problem. Mycologist 20:99-104

Wilson JGM (1976) Immunological aspects of fungal disease in fish. In: Gareth Jones EB (ed) Recent advances in aquatic mycology. Elek Science, London, p 573-601

Wood SW, Willoughby LG, Beakes GW (1986) Preliminary evidence for inhibition of Saprolegnia fungus in the mucus of brown trout, Salmo trutta L., following experimental challenge. J Fish Dis 9:557-560

Submitted: July 30, 2008; Accepted: October 20, 2008

Proofs received from author(s): December 18, 2008 